(ㄷ) Entomologica Fennica. Vol. 3:171. 19.X.1992

\title{
Parasigara multillineata de Sallier Dupin, 1973, a synonym of Corixa monticola Linnavuori, 1971, and notes on distribution of African species of Corixa (Heteroptera, Corixidae)
}

\author{
Antti Jansson \\ Zoological Museum, University of Helsinki, P. Rautatiekatu 13, SF-00100 Helsinki, Finland
}

Linnavuori (1971) described two new species of Corixa from Ethiopia. The descriptions were very short, and the illustrations inadequate when compared to the traditional style of illustrating descriptions of new species of Corixidae; Figs. 1-10 amend Linnavuori's illustrations.

Having had an opportunity to investigate the type materials of Corixa monticola Linnavuori, 1971:349 (holotype ơ in the American Museum of Natural History, New York) and Parasigara multilineata de Sallier Dupin 1973:7 (holotype $O^{7}$ slide preparation in Rennes, France ${ }^{1}$ ), I can hereby report that the two are conspecific. Thus, $P$. multilineata must be rejected as a junior synonym of $C$. monticola. De Sallier Dupin's reasons for the generic placing of the taxon are totally unclear to me.

Altogether seven species of Corixa are known from Africa. Their synonymy and distribution known to me is as follows:

C. affinis Leach, $1817: 18$

= Sigara atomaria Illiger, 1807:354; invalid name (Jaczewski 1962, Opinion 687 / 1964)

= Corixa graphiptera Rambur, 1840:192 (Puton 1874)

= Corisa platycnemis Fieber, 1851:16 (Jansson 1981)

= Corixa atomaria var. conglomerata Rey, 1890:29 (Jansson 1981)

= Corixa affinis var. pallida Poisson, 1929:93 (Jansson 1981)

\footnotetext{
${ }^{1}$ Vanni et al. (1986) listed the holotype of P. multilineata being deposited in the Firenze University Museum, but since the original description was based on a single male, and the specimen in Firenze is a female, the latter does not belong to the type material.
}

Distribution generally SW Palearctic, in Africa known from the Canary Islands, Mauritania, Morocco, Algeria, Tunisia, Libya, and Egypt.

\section{C. frigidae Linnavuori, 1971:349}

Distribution: Ethiopia and Sudan.

C. mirandella Hutchinson, 1930:60

Distribution: Kenya.

C. monticola Linnavuori, 1971:349

= Parasigara multilineata de Sallier Dupin, 1973:7, new synonymy

Distribution: Ethiopia.

C. panzeri (Fieber, 1848:515)

= Corisa macrocephala Fieber, 1848:516 (Lundblad 1936)

= Corixa charadrina Gistel, 1857:70 (Jansson 1986)

= Corisa (Macrocorisa) salina Thomson, 1869:29, not Puton 1872 (Puton 1886)

Distribution generally SW Palearctic, in Africa known from Morocco and Algeria.

C. pseudaffinis Poisson, 1950:88

Distribution: Zaire.

C. punctata (Illiger, 1807:354)

= Corixa geoffroyi Leach, 1817:17 (China 1938, Opinion 281 / 1954)

= Corisa xanthosoma Fieber, 1848:514 (Jansson 1981)

Distribution generally SW Palearctic, in Africa known from the Canary Islands, Morocco, Algeria, and Tunisia. 

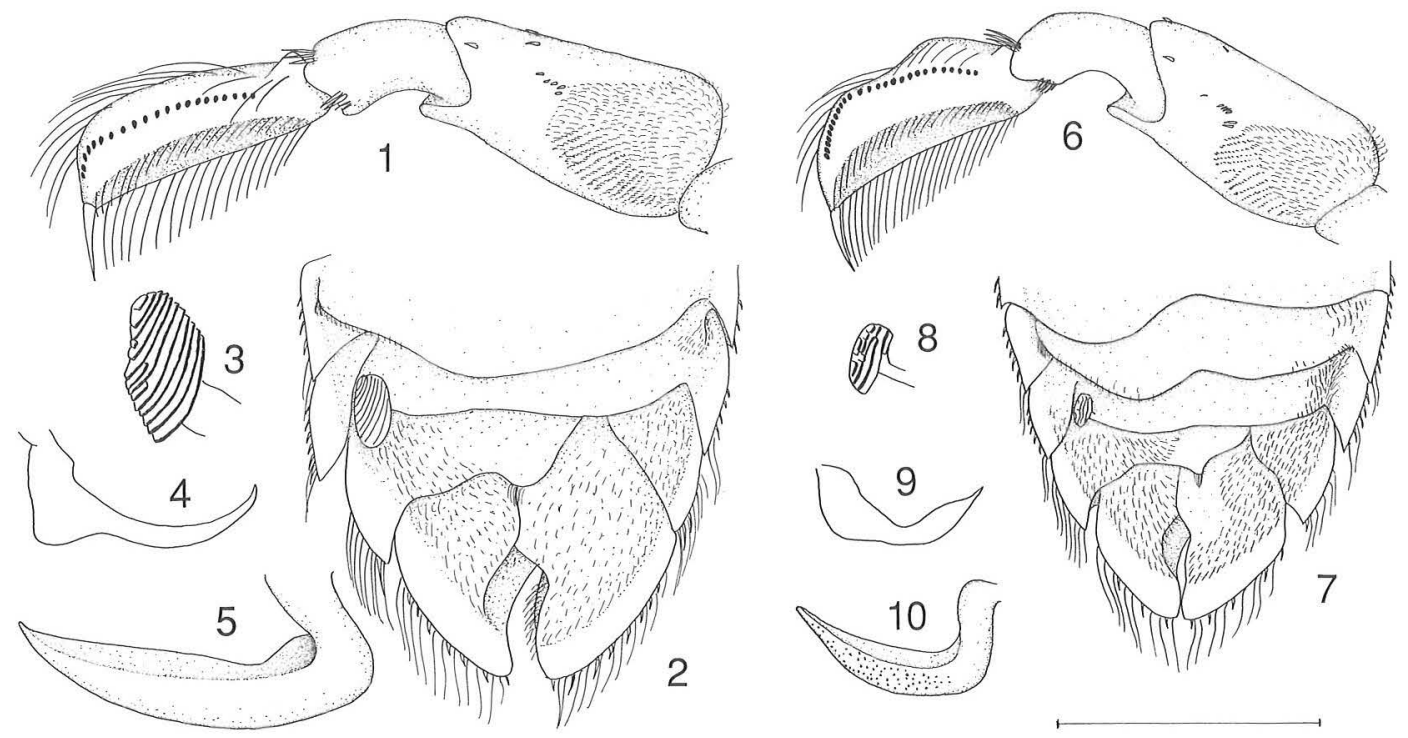

Figs. 1-10. Male characteristics of Corixa frigidae Linnavuori (1-5) and C. monticola Linnavuori (6-10): fore leg, abdominal dorsum, strigil in detail, and right and left paramere. - Scale line: $2 \mathrm{~mm}$ for Figs. $2 \& 7,1 \mathrm{~mm}$ for the rest.

\section{References}

China, W. E. 1938: Notes on the nomenclature of British Corixidae. - Entomol. Mon. Mag. 74:34-39.

Fieber, F. X. 1848: Synopsis aller bisher in Europa entdecten Arten der Gattung Corisa. - Bull. Soc. Imp. Nat. Moscou 21:505-593.

- 1851: Species generis Corisa. - J. G. Calve, Pragae, $31 \mathrm{pp}$.

Gistel, J. 1857: Achthundert und zwanzig neue oder unbeschriebene wirbellose Tiere. - Straubing, 94 pp.

Hutchinson, G. E. 1930: Fisheries survey of Lakes Albert and Kioga: Report on Notonectidae and Corixidae. Ann Mag. Nat. Hist. (ser. 10) 1930:57-65.

Illiger, C. 1807: Fauna Etrusca ... - Helmstad, tom. 2, 511 pp.

Jansson, A. 1981: A new European species and notes on synonymy in the genus Corixa Geoffroy (Heteroptera, Corixidae). - Ann. Entomol. Fennici 47:65-68.

- 1986: The Corixidae (Heteroptera) of Europe and some adjacent regions. - Acta Entomol. Fennica 47:1-94.

Leach, W. E. 1817: On the classification of the natural tribe of insects Notonectides, with descriptions of British species. - Trans. Linn. Soc. London 12:10-18.

Linnavuori, R. E. 1971: Hemiptera of the Sudan, with remarks on some species of the adjacent countries. 1 . The aquatic and subaquatic families. - Ann. Zool. Fennici 8:340-366.

Lundblad, O. 1936: De svenska vettenhemipterernas ekologi och djurgeografiska ställning. - Entomol. Tidskr. 57:29-74.
Poisson, R. 1929: Résultats scientifiques de la mission du Hoggar (1928) - Hémiptères aquatiques. - Bull. Soc. Hist. Nat. Afr. Nord. 20:87-96.

- 1950: Sur quelques espèces nouvelles d'Hydrocorises des collections du Musée du Congo belge. - Rev. Zool. Bot. Afr. 43:67-91.

Puton, A. 1872: Descriptions d'especes nouvelles ou peu connues d'Hémiptères d'Europe et d'Algerie. — Mitt. Schweiz. Entomol. Ges. 3:425-426.

- 1874: Notes pour servir l'étude des Hémiptères. Ann. Soc. Entomol. France 5:213-234.

- 1886: Catalogue des Hémiptères (Héteroptères, Cicadines et Psyllides) de la faune paléarctique. 3-e éd. Rev. d'Entomol. 5 (Suppl.), 100 pp.

Rambur, M. P. 1840: Heteroptera. - Faune Entomol. Andalousie 2:95-212.

Rey, C. 1890: Observations sur quelques Hémiptères et descriptions d'espèces nouvelles ou peu connues. Rev. d'Entomol. 9:2932.

de Sallier Dupin, F. 1973: Hétéroptères Hydrocorises de l'Afrique Orientale. - Monit. Zool. Italiano N.S. Suppl. 5 No. 1:1-14.

Thomson, C. G. 1869: Öfversigt af Sveriges Coriser. Thomson's Opusc. Entomol. 1 (2):26-40.

Vanni, S., Bartolozzi, L. \& Whitman-Mascherini, S. 1986: Cataloghi del Museo di Storia Naturale dell'Universtá di Firenze - Sezione di Zoologia. IV. Insecta Isoptera e Insecta Hemiptera: Tipi. - Atti Soc. Toscana Sci. Nat. Mem. (B) 92:241-245.

Received 10.III.1992 